\title{
GÊNESE E EVOLUÇÃO DA LAGOA DOURADA, PONTA GROSSA, PR
}

\author{
Mário Sérgio de MELO \\ Paulo César Fonseca GIANNINI \\ Luiz Carlos Ruiz PESSENDA
}

\begin{abstract}
RESUMO
A Lagoa Dourada é uma das depressões do sistema de furnas do Parque Estadual de Vila Velha, formada sobre o Arenito Furnas. Ela tem cerca de $200 \mathrm{~m}$.de diâmetro e lâmina d'água de até 5,4 m. Situa-se na bacia hidrográfica do Rio Guabiroba, um afluente do alto Rio Tibagi na região dos Campos Gerais no Estado do Paraná. O sedimento que preenche a Lagoa Dourada é silto-argiloso nos dois terços de sul e sudeste, passando a arenoso no terço norte e noroeste. O material silto-argiloso provém das águas turvas de inundações do Rio Guabiroba, o material arenoso provém de surgências de água subterrânea. As taxas de sedimentação são comparáveis às de outras lagoas em planícies de inundação do sudeste do Brasil. Nos sedimentos arenosos da lagoa a ocorrência acentuada de epídoto e anatásio pode indicar que parte da água subterrânea provém de grandes profundidades (mais de 300 metros, espessura da Formação Furnas na área), transportando grãos dos metassedimentos subjacentes. Isto conduziria à antiga hipótese de que a origem das furnas possa estar relacionada com fenômenos de erosão subterrânea profundos, incluindo dissolução. A ocorrência de gipso e pirita nos sedimentos da lagoa, ambos autígenos, sugere fases de aumento da salinidade das águas durante a sedimentação, relacionadas a maior evaporação em climas mais secos. "Ciclos" de aumento das taxas de carbono total nos sedimentos apresentam correspondência com o aumento das relações isotópicas ${ }^{13} \mathrm{C} /{ }^{12} \mathrm{C}$ $\left(\delta^{13} \mathrm{C}\right)$, podendo indicar tendência para fases climáticas mais secas e/ou variações na salinidade da água. A idade da Lagoa Dourada é mais antiga que 11.170 anos, datação dos restos vegetais da base de testemunho de sondagem, o qual não atingiu o embasamento dos sedimentos. Por outro lado, algumas das furnas não são feições antigas, como sugere a furna $n^{\circ} 4$ do Parque Estadual de Vila Velha, a qual situa-se no leito de drenagem seca a jusante da furna. Pode-se especular que a erosão subterrânea que origina as furnas tenha maior eficiência durante fases de pronunciado rebaixamento do lençol freático, o que aconteceu durante as fases de clima mais seco associadas aos períodos glaciais do Pleistoceno.
\end{abstract}

Palavras-chave: Lagoa Dourada, furna assoreada, sedimentação cenozóica, paleoclimas cenozóicos.

\section{ABSTRACT}

The Lagoa Dourada belongs to the furnas system of the Vila Velha State Park, state of Paraná, southern Brazil. It is a roughly circular depression in the Furnas Sandstone (Devonian of the Paraná Basin), with a diameter of about $200 \mathrm{~m}$ and a water column up to $5.4 \mathrm{~m}$ deep. It contains at least 12.2 $\mathrm{m}$ of sediments of the Holocene and end of the Pleistocene. In the last 12,000 years the Lagoa Dourada has been filled by sands brought by sources of underground waters as well as by mud brought by the floods of the Guabiroba River, a tributary of the upper Tibagi River. The furnas are sinkholes formed in the Furnas Sandstone. Lagoa Dourada is considered to be a silted-up furna, a consequence of invasion by floodwaters of the Guabiroba River. Data from a core sample of the sediments show that the grain size is predominantly silt and clay in the southern and southeastern two thirds, changing to sand in the northern and northwestern third. The occurrence of gypsum and pyrite in the sediments, both authigenic, suggests periods of increase in the water salinity, related to greater evaporation in drier climates. "Cycles" of increase in total carbon rates in the sediments coincide with the increase in the isotopic ratios ${ }^{13} \mathrm{C} /{ }^{12} \mathrm{C}\left(\delta^{13} \mathrm{C}\right)$, indicating variations in the vegetation, with greater participation of grasses and consequently an increase in $\delta^{13} \mathrm{C}$, suggesting trends to drier climatic phases and/or variations in the salinity of the pond water. The sedimentation rates should reach $0.53 \mathrm{~mm} / \mathrm{year}$ between 11.9 and $10.6 \mathrm{~m}$ deep, and $1.22 \mathrm{~mm} /$ year above $10.6 \mathrm{~m}$ deep. These rates are similar to those of other Holocene flood plain ponds in southeastern Brazil. Lagoa Dourada is older than 11,170 years, as judged from dates of plant remains in the base of the core sample, which did not reach the bedrock. On the other hand, some of the furnas must be not old features, as suggested by furna $\mathrm{n}^{\circ} 4$ of the Vila Velha State Park, which is placed in the stream bed of a brook, dry downstream from the furna. It can be speculated that the subterranean erosion that originates the furnas has more efficiency during phases of pronounced lowering of the water table, which happen during the drier climates associated to Pleistocene glacial periods.

Keywords: Lagoa Dourada, Furnas Formation, silted-up furna, sandstone sinkhole, Cenozoic sedimentation, Cenozoic palaeoclimates. 


\section{INTRODUÇÃO}

A Lagoa Dourada é uma depressão formada sobre o Arenito Furnas, com cerca de 200 m de diâmetro e lâmina d'água de até 5,4 m, situada na bacia hidrográfica do Rio Guabiroba, um afluente do alto Rio Tibagi no Estado do Paraná. Ela faz parte do sistema de furnas do Parque Estadual de Vila Velha (Figura 1), situando-se cerca de $20 \mathrm{~km}$ a sudeste do centro da cidade de Ponta Grossa, e $70 \mathrm{~km}$ a noroeste de Curitiba.

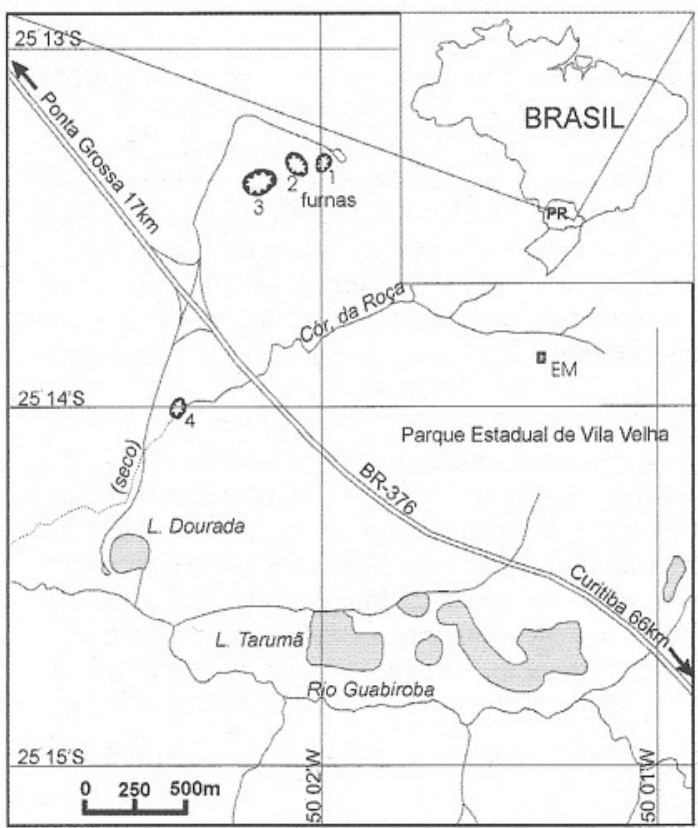

FIGURA 1 - Mapa de localização da Lagoa Dourada (modificado de SOARES 1989). 1-4: furnas do Parque Estadual de Vila Velha; EM: Estação Meteorológica do IAPAR.

A Lagoa Dourada constitui um dos três atrativos geológico-geomorfológicos do Parque Estadual de Vila Velha, juntamente com o relevo ruiniforme em arenitos e as furnas. Segundo dados da Paranaturismo, o Parque Estadual tem recebido, ao longo da última década, média de 150 mil visitantes/ano, provenientes de muitos locais do Brasil e de todo o mundo.

A lagoa atrai principalmente por sua beleza, sendo preenchida por águas límpidas provenientes de fontes subterrâneas, onde se pode observar várias espécies de peixes da região, que nela encontram águas relativamente quentes e abrigo para reprodução. A lagoa é contornada por mata ciliar representada por floresta ombrófila mista onde se destaca o pinheiro araucária, o que completa cenário muito aprazível.

A intensa visitação já tem feito sentir suas conseqüências na Lagoa Dourada, como a erosão nas trilhas mais usadas e assoreamento da lagoa. Não existe plano de manejo adequado nas áreas limítrofes, utilizadas pelo IAPAR para pesquisas agropecuárias, o que vem colocando em risco também a preservação dos remanescentes de mata ciliar e da fauna local. Além disso, embora objeto de estudos ictiológicos, paleolimnológicos, micropaleontológicos, sedimentológicos e geomorfológicos, a informação divulgada sobre a Lagoa Dourada muitas vezes é incorreta, o que se pode observar no site da Paranaturismo e em painéis expostos nos locais de visitação.

\section{MÉTODOS E TÉCNICAS}

As interpretações sobre a gênese e evolução da Lagoa Dourada basearam-se em dados resultantes de levantamento bibliográfico, compilação de cartas geológicas preexistentes, levantamentos de campo na área da lagoa e bacia hidrográfica do Rio Guabiroba, análise de dados pluviométricos e fluviométricos, análise de mosaico de radar do Projeto RADAMBRASIL (1976), em escala 1:250.000, fotointerpretação de fotografias aéreas em escala 1:25.000 (ITC-PR, 1980) e 1:8.000 (FAMEPAR-PMPG, 1995) e resultados de análise sedimentológica de testemunho de sondagem (MELO 1999, MELO et al. s.d.a e s.d.b, MELO 2000).

\section{GEOMORFOLOGIA DA REGIÃO ESTUDADA}

A Lagoa Dourada situa-se na bacia hidrográfica do Rio Guabiroba, um tributário do alto Rio Tibagi, o qual tem suas nascentes nas bordas do Segundo Planalto Paranaense. Este planalto constitui um dos compartimentos do relevo escalonado do Estado do Paraná (Figura 2), com topos nivelados entre 1100 e $800 \mathrm{~m}$, com suave caimento para oeste.

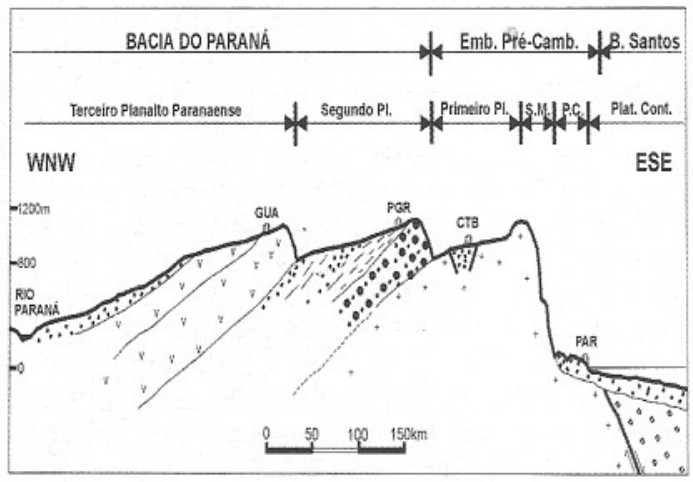

FIGURA 2 - Seção esquemática do Estado do Paraná mostrando a estrutura geológica do relevo. P.C.: Planície Costeira; S.M.: Serra do Mar; PAR: Paranaguá; CTB: Curitiba; PGR: Ponta Grossa; GUA: Guarapuava.

Rochas sedimentares paleozóicas da Bacia do Paraná, com algumas intrusivas básicas associadas, sustentam o Segundo Planalto 
Paranaense. Este é delimitado por dois marcantes degraus topográficos, cada um deles com cerca de 300 m de desnível, representados pela "Escarpa Devoniana" a leste e Serra Geral a oeste.

\subsection{Características geomorfológicas da bacia hidrográfica do Rio Guabiroba}

A bacia hidrográfica do Rio Guabiroba, à qual pertence a Lagoa Dourada, tem forma aproximadamente triangular, com cerca de $360 \mathrm{~km}^{2}$ de superfície (Figura 7). O Rio Guabiroba corresponde à base do triângulo. Apresenta direção WNW-ESE, com sentido da drenagem para WNW. Esta direção geral é subparalela a importantes estruturas rúpteis da área, notando-se, nas cabeceiras do Rio Guabiroba, trechos com nítido controle por estas estruturas.

O Rio Quebra Perna, importante tributário da margem direita do Rio Guabiroba, apresenta direção NNE-SSW, com sentido da drenagem para SSW, com marcante controle estrutural. Esta direção é paralela ao limite entre a bacia hidrográfica do Rio Guabiroba e a do Rio Botuquara, situada a noroeste. Nas cabeceiras da sub-bacia do Rio Quebra Perna nota-se localmente padrão de drenagem em treliça, resultante do controle por estruturas nas direções NNE-SSW e WNW-ESE.

O limite nordeste da bacia do Rio Guabiroba corresponde grosseiramente ao limite das unidades da Bacia do Paraná sobre o embasamento cristalino, um limite erosivo, mas com marcante controle pelas estruturas WNW-ESE, que freqüentemente alojam diques de diabásio. Este limite corresponde à "Escarpa Devoniana", que separa o Segundo do Primeiro Planalto Paranaense, onde aparecem já os rios da Areia e Guarituba, ambos já da bacia hidrográfica do Rio Ribeira.

A leste e sul da bacia hidrográfica do Rio Guabiroba aparecem terrenos que são drenados diretamente para o Rio Tibagi, do qual o primeiro é tributário.

Os topos das elevações na bacia do Rio Guabiroba variam de $1.117 \mathrm{~m}$ sobre o nível do mar (s.n.m). a nordeste até $865 \mathrm{~m}$ s.n.m. a sudoeste, configurando aproximadamente a mesma tendência geral de caimento dos topos para oeste, observada no Segundo Planalto Paranaense. Segundo dados do FAMEPAR (1995) a cota do nível d'água do Rio Guabiroba na confluência com o Rio Tibagi é de $781 \mathrm{~m}$ s.n.m.

O relevo na bacia hidrográfica do Rio Guabiroba apresenta características marcantes. O Arenito Vila Velha, unidade geológica de topo na região, usualmente sustenta platôs limitados por cornijas com até duas dezenas de metros de desnível. Vários inselbergs do Arenito Vila Velha estão muito desfeitos pela erosão, constituindo sítios de rara beleza, os chamados "relevos ruiniformes" (AB'SÁBER 1977, MELO \& COIMBRA 1996). Outra feição típica presente no local são as "furnas", descritas no item seguinte.

Excetuando-se os platôs, cornijas, inselbergs com relevos ruiniformes e as furnas, predominam na região relevos colinosos, com planícies aluviais bem desenvolvidas, configurandose bacia relativamente matura, com baixo poder de entalhamento dos talvegues.

\subsection{Características geomorfológicas da Lagoa Dourada e vizinhanças}

A Lagoa Dourada é um corpo d'água aproximadamente elíptico com eixo maior na direção NNE-SSW com cerca de 200 m e eixo menor na direção WNW-ESE com cerca de $160 \mathrm{~m}$ de comprimento (Figura 3). A área da bacia de captação que drena diretamente para a lagoa é muito pequena (cerca de $18 \mathrm{ha}$ ). Um estreito cinturão preservado de mata ciliar nativa protege a maior parte do perímetro da lagoa.

Durante a coleta de testemunho de sondagem dos sedimentos da lagoa realizada em novembro de 1991, foi constatada, através de equipamento de sonar, uma lâmina d'água variando entre 0,4 e 5,4 m (MORO 1998), a mesma que havia sido descrita por MAACK (1946). Embora estas cifras sugiram que no geral o assoreamento no período não tenha sido significativo, observações no terreno e na fotografia aérea em escala 1:8.000 do FAMEPAR em 1995 (Figura 3) mostram que o assoreamento é expressivo na borda sul da lagoa, onde há muito solo exposto nas margens, sujeito a erosão laminar e em sulcos, nas trilhas usadas pelos turistas que visitam o local.

A borda SW da lagoa dista cerca de 110 $\mathrm{m}$, em linha reta, do leito do Rio Guabiroba, ao qual está conectada por um canal tortuoso com cerca de $220 \mathrm{~m}$ de extensão, com largura média da ordem de dois metros, e profundidade média da ordem de 1,5 metros. A cota do nível d'água na lagoa é de 788,4 m s.n.m., enquanto a cota do nível d'água normal do Rio Guabiroba no local é de 787,0 m s.n.m. (MAACK 1946). Este desnível relativamente pequeno $(1,4 \mathrm{~m})$ justifica as freqüentes incursões de águas barrentas do Rio Guabiroba para o interior da Lagoa Dourada, durante as cheias que seguem chuvas mais intensas.

tes cotas:

As bordas da lagoa apresentam as seguin-

a) $800 \mathrm{~m}$, junto ao canal de comunicação com o Rio Guabiroba, na planície aluvial a S e SE;

b) $805 \mathrm{~m}$, a SW, onde se situa o estacionamento para visitantes;

c) até $812 \mathrm{~m}$, no flanco norte, onde ocorrem pequenos escarpamentos verticais sustentados pelo Arenito Furnas, com até pouco mais de uma dezena de metros de desnível.

A Lagoa Dourada é considerada como sendo uma das seis depressões denominadas "furnas" que ocorrem no Parque Estadual de Vila Velha, as quais podem ser assim descritas (MAACK 1956 e SOARES 1989, Figuras 1 e 8):

a) furna $\mathrm{n}^{\circ} 1$ : situada mais a nordeste, com abertura na cota $848 \mathrm{~m}$ s.n.m., é a que possui forma mais circular, com 80 m de diâmetro e 111 


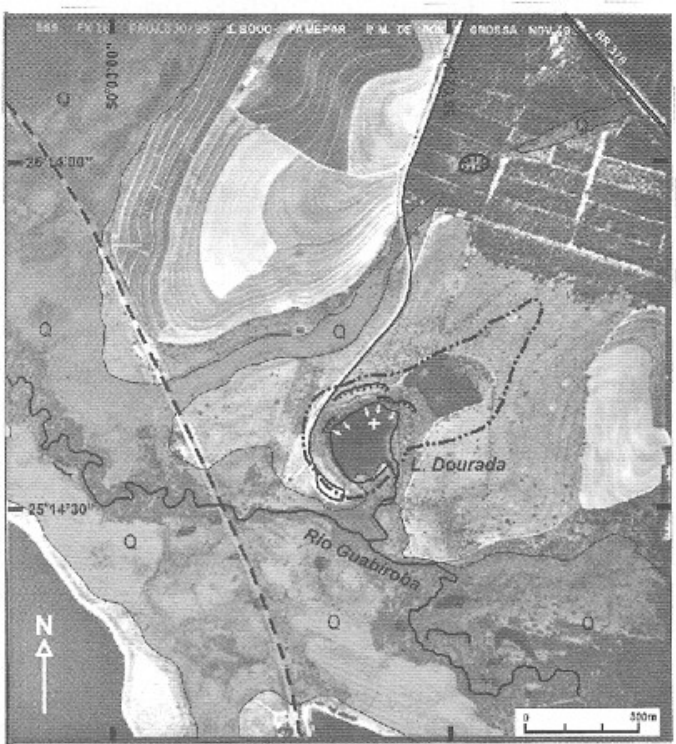

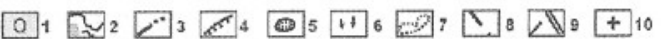

FIGURA 3 - Geologia, geomorfologia e uso do solo nas vizinhanças da Lagoa Dourada. 1: planícies aluviais quaternárias; 2 : rios, lagos e meandros abandonados; 3 : limite da área que drena para a Lagoa Dourada; 4: rupturas de declive acentuadas; 5 : furna; 6: surgências d'água subterrânea; 7: área assoreada da Lagoa Dourada; 8: estrada de ferro; 9: estradas de rodagem; 10: local de coleta do testemunho de sondagem (baseado em FAMEPAR 1995). Observa-se áreas claras com cultivo sazonal, áreas escuras com reflorestamento, áreas cinzentas com vegetação de campos e matas ciliares ao longo do Rio Guabiroba e nas bordas da Lagoa Dourada.

$\mathrm{m}$ de profundidade total, dos quais $53,2 \mathrm{~m}$ estão abaixo do lençol freático, apresentando-se inundados; aparentemente o fundo é constituído de rochas da Formação Furnas, sem sedimentos jovens sobrepostos (SOARES 1989); apresenta um elevador e uma plataforma flutuante para turistas;

b) furna $n^{\circ} 2$ : situada cerca de uma centena de metros a WSW da primeira, com abertura na cota 842 m s.n.m., tem forma elíptica com eixo maior com cerca de $150 \mathrm{~m}$ de comprimento, e profundidade total de $110 \mathrm{~m}$, dos quais $56,4 \mathrm{~m}$ inundados;

c) furna $\mathrm{n}^{\circ} 3$ : situada cerca de $200 \mathrm{~m}$ a WSW da anterior, as três estão num aparente alinhamento estrutural; com abertura na cota 842 m s.n.m., apresenta forma elíptica com eixo maior com cerca de $100 \mathrm{~m}$, e profundidade de $20 \mathrm{~m}$, não chegando a atingir o lençol freático; é considerada como uma depressão em que a erosão subterrânea e conseqüente desabamento não foram processos tão marcantes como nas demais furnas;

d) furna $\mathrm{n}^{\circ}$ 4: situada cerca de $1 \mathrm{~km}$ a SSE da anterior e 640 m a NNE da Lagoa Dourada, com abertura na cota 824 m s.n.m.; apresenta forma elíptica com eixo maior de $21 \mathrm{~m}$, e profundidade de $43,5 \mathrm{~m}$, dos quais 13,9 submersos; recebe as águas do Córrego da Roça, que tem nela um sumidouro, razão pela qual estaria em processo de assoreamento mais rápido; aparentemente trata-se de uma furna de desenvolvimento muito recente, visto que a jusante ainda aparece o leito seco bem preservado do Córrego da Roça;

e) Lagoa Dourada: é considerada uma furna assoreada, o que se deve à sua proximidade atual com o Rio Guabiroba, que a invade com águas barrentas durante as enchentes; a profundidade total conhecida é de pelo menos $36 \mathrm{~m}$, dos quais $24 \mathrm{~m}$ de desnível topográfico e $12 \mathrm{~m}$ de espessura de sedimentos atravessados durante a coleta do testemunho de sondagem;

f) Lagoa Tarumã: situada na planície aluvial do Rio Guabiroba cerca de 1,2 km a montante da Lagoa Dourada; tem forma irregular, com cerca de $300 \mathrm{~m}$ de eixo maior, e 5,7 $\mathrm{m}$ de lâmina d'água.

As "furnas" são interpretadas como poços de desabamento semelhantes às dolinas, mas formadas em arenitos, no caso o Arenito Furnas. Resultam da erosão subterrânea favorecida ao longo de direções estruturais, formando túneis, cujos tetos localmente desabam formando as depressões no terreno (MAACK 1956, SOARES 1989).

\section{CLIMA}

O clima na região do Segundo Planalto Paranaense onde se situa a Lagoa Dourada apresenta estações termicamente bem definidas, sendo a média do mês mais quente (fevereiro) de $21,2^{\circ} \mathrm{C}$ e a do mês mais frio (julho) $13,3^{\circ} \mathrm{C}$ (MAACK 1981). O clima vigente é do tipo $C f b$ do Sistema Internacional de Classificação de Climas de Köppen, isto é, um clima quente-temperado e sempre úmido, o mês mais quente com média inferior a $22^{\circ} \mathrm{C}$, onze meses do ano com média superior a $10^{\circ} \mathrm{C}$, e mais de cinco geadas noturnas por ano (MAACK 1981). A temperatura média anual é de $18^{\circ} \mathrm{C}$, com máxima absoluta de $36,2^{\circ} \mathrm{C}(08 / 01 / 58)$ e mínima absoluta de $-5,8^{\circ} \mathrm{C}(06 / 08 / 63)$. A precipitação média é de $1.542 \mathrm{~mm}$ anuais. As chuvas são bem distribuídas ao longo do ano, com declínio pouco acentuado nos meses de abril a agosto (Figura 4, dados da Estação Meteorológica do IAPAR em Vila Velha, período 1954-98).

\section{VEGETAÇÃO}

A região onde se situa a Lagoa Dourada é denominada "Campos Gerais do Paraná" (MAACK 1948). Caracteriza-se como região fitogeográfica dominada por campos limpos com capões e matas ciliares de floresta de Araucaria. Situa-se na borda do Segundo Planalto 


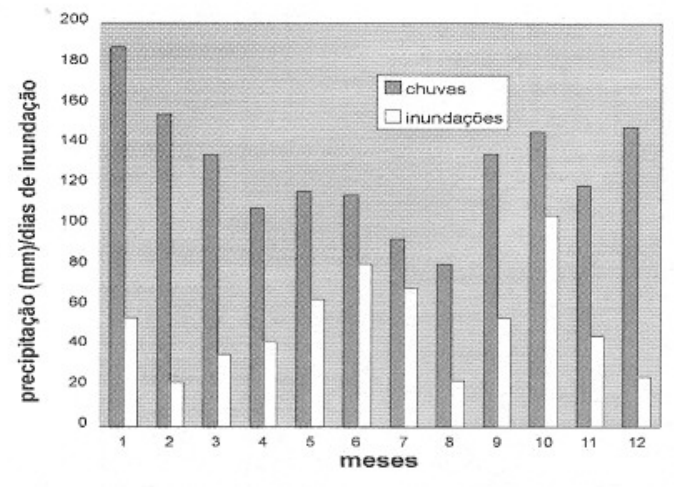

FIGURA 4 - Precipitação média mensal (1954-98) e total de dias de inundação (1974-98) na bacia do alto Tibagi, PR.

Paranaense, estendendo-se por uma faixa contínua desde o limite com Santa Catarina, a sul, até o limite com São Paulo, a norte.

Predominam nos Campos Gerais os campos limpos do tipo savana gramíneo-lenhosa (MORO 1998), que ocupam a maioria dos topos das elevações e encostas. A uniformidade fisionômica dos campos é interrompida pela ocorrência de matas de Araucaria, que aparecem na forma de matas ciliares (freqüentemente encaixadas no fundo de vales na forma de canyons) ou em capões isolados. Tal formação florestal é incluída na zona fitoecológica da Floresta Ombrófila Mista (VELOSO \& GOES-FILHO 1982), situando-se na denominada "região dos campos limpos com capões e matas ciliares ou galerias ao longo dos rios e arroios (também zonas de Araucaria)" de MAACK (1981).

A vegetação nos campos é formada principalmente por gramíneas, ciperáceas, compostas, verbenáceas e leguminosas, que formam cobertura herbácea densa (MORO 1998).

Nos capões distinguem-se diversos estágios de sucessão. Nos núcleos pioneiros predominam espécies heliófilas das famílias Myrtaceae, Anacardiaceae e Euphorbiaceae, com ausência da Araucaria. Nos núcleos mais evoluídos "...a Araucaria encontra-se circundada por uma submata de Myrtaceae e Lauraceae, em cuja orla ocorrem abundantemente Melastomataceae e Compositae" (MORO 1998, p.14).

Nas matas que acompanham os cursos e corpos d'água, como é o caso da Lagoa Dourada, além das famílias que aparecem nos núcleos mais evoluídos descritos acima, ocorrem também Palmae, taquaras e pteridófitas (samambaias). Nos estágios mais evoluídos das matas ciliares aparece também o angico (Leguminosae), embora este não seja observado na borda da Lagoa Dourada.

\section{GEOLOGIA REGIONAL}

A região da Lagoa Dourada localiza-se no flanco oriental da Bacia do Paraná, onde esta é profundamente afetada pelo Arco de Ponta Grossa, responsável pela elevação e arqueamento do embasamento proterozóico e das camadas sedimentares da bacia, e por extensas fraturas NW$\mathrm{SE}$ que deram passagem a grande volume de magma basáltico no Mesozóico. As unidades da Bacia do Paraná presentes na área estudada são as formações Furnas e Ponta Grossa (Devoniano), e a base do Grupo Itararé (Carbonífero Superior).

A região da Lagoa Dourada situa-se no flanco sudoeste do Arco de Ponta Grossa (Figura 5), uma importante estrutura de direção NW-SE da Bacia do Paraná. É um arqueamento na forma de alto estrutural com eixo inclinado para NW, ativo desde o Paleozóico, mas palco de intensa atividade tectônica sobretudo no Mesozóico. Nesta época, os movimentos verticais ao longo do arqueamento atingiram seu apogeu, e profundas fraturas longitudinais deram passagem ao magma formador dos extensos derrames da Formação Serra Geral, que aparecem no Terceiro Planalto Paranaense, na porção oeste do Estado.

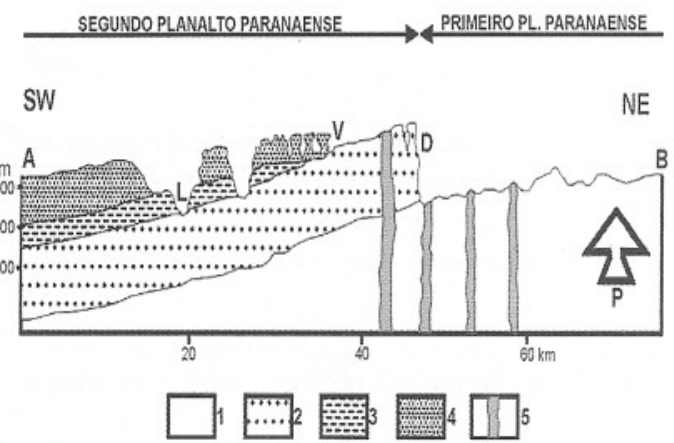

FIGURA 5 - seção geológica esquemática passando pela Lagoa Dourada e Vila Velha (A-B na Figura 7). 1: embasamento proterozóico; 2: Formação Furnas (D); 3: Formação Ponta Grossa (D); 4: Grupo Itararé (C-P); 5: diques de diabásio (Mesozóico); V: Vila Velha; L: Lagoa Dourada; D: Escarpa Devoniana; P: arqueamento máximo do Arco de Ponta Grossa.

O Arco de Ponta Grossa é o responsável por algumas das feições geológicas e geomorfológicas mais notáveis do flanco leste da Bacia do Paraná:

a) fraturas, falhas e enxames de diques, predominantemente de diabásio, de direção NW$\mathrm{SE}$, os quais controlam o relevo e hidrografia locais;

b) concavidade do contato dos sedimentos paleozóicos da Bacia do Paraná sobre o embasamento; esta reentrância corresponde à remoção erosiva dos sedimentos paleozóicos nas porções mais soerguidas do arqueamento;

c) escalonamento do relevo em planaltos de origem erosiva no Estado do Paraná, resultantes da conjugação do efeito do levantamento tectônico no Ảrco de Ponta Grossa com a 


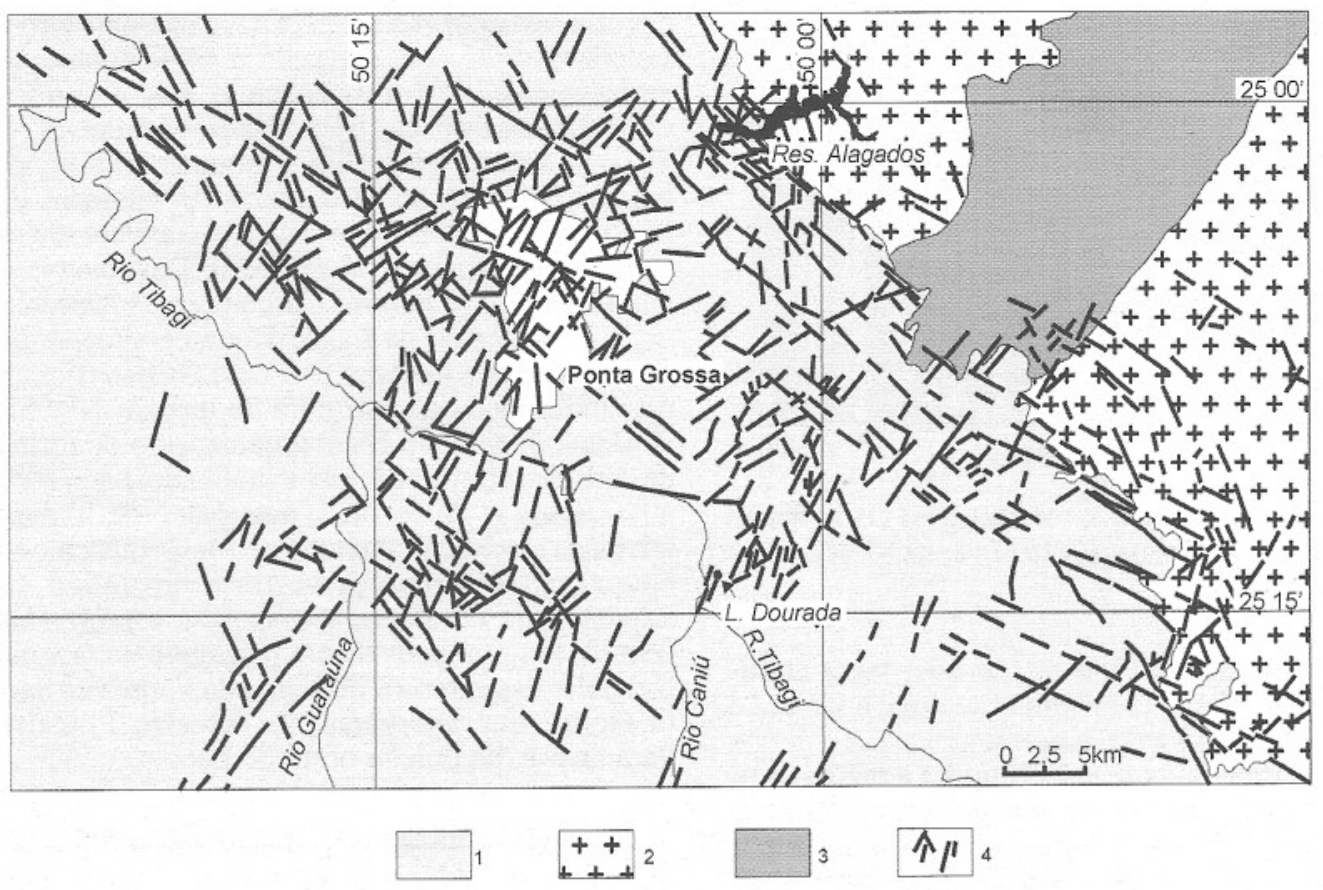

FIGURA 6 - Lineamentos estruturais na borda da Bacia do Paraná onde se situa a Lagoa Dourada. 1: rochas sedimentares paleozóicas da Bacia do Paraná; 2: predominantemente rochas granitóides neoproterozóicas; 3 : rochas metamórficas meso a neoproterozóicas da Faixa Itaiacoca; 4: lineamentos estruturais extraídos de mosaico de radar. Base geológica modificada de MINEROPAR (1989).

erosão diferencial agindo sobre as rochas da Bacia do Paraná e embasamento proterozóico (Figura 5).

Reconhecem-se três direções principais de estruturas tectônicas na Bacia do Paraná (ZALÁN et al. 1991):

a) NE-SW, correspondente às direções do embasamento proterozóico da bacia (cinturões de dobramentos, zonas de cisalhamento), reativadas recorrentemente durante a evolução da bacia, com movimentos horizontais e verticais;

b) NW-SE, preexistentes e reativadas principalmente no Neojurássico e Eocretáceo, com movimentos verticais dominantes; associamse à ruptura do Gondwana e magmatismo da Formação Serra Geral;

c) E-W, supostamente originadas a partir do Triássico, ligados à abertura do Atlântico Sul, em vista do paralelismo com as zonas de fraturas oceânicas.

Todas estas direções estruturais principais foram reativadas durante os movimentos ao longo do Arco de Ponta Grossa, no Mesozóico, e ocorrem na região da bacia hidrográfica do Rio Tibagi e da Lagoa Dourada, impondo marcante controle estrutural da drenagem, sobretudo do Rio Quebra Perna. A observação da Figura 6 revela ainda alta concentração de lineamentos estruturais (falhas, fraturas, diques) na continuidade, por sob as rochas sedimentares da Bacia do Paraná, da Faixa Itaiacoca, sugerindo que as rochas e es- truturas do substrato proterozóico possam de fato estar condicionando as estruturas e a evolução morfológica superficial, como já suposto por MAACK (1946 e 1956).

\section{A ORIGEM E EVOLUÇÃO DAS FURNAS E DA LAGOA DOURADA}

As feições de abatimento denominadas "furnas", incluindo a Lagoa Dourada, considerada uma furna assoreada, aparecem principalmente na borda do Segundo Planalto Paranaense, onde ocorrem as porções basais do Arenito Furnas, com marcado caráter arcoseano (Figura 7).

\subsection{Trabalhos prévios sobre as furnas e a Lagoa} Dourada

De acordo com SOARES (1989) o primeiro trabalho digno de referência a respeito das furnas de Vila Velha deveu-se ao professor curitibano Nivaldo Teixeira Braga, que estudou a região em 1888, conforme registro de TAUNAY (1889, apud SOARES 1989) em memória lida no Instituto Histórico e Geográfico Brasileiro, que continha a seguinte descrição: "Com a denominação genérica e vaga de Buracos são conhecidas três profundas perfurações naturais do solo, que demoram na parte oriental da fazenda do Capão Grande... Diz o Sr. Nivaldo Braga que à 


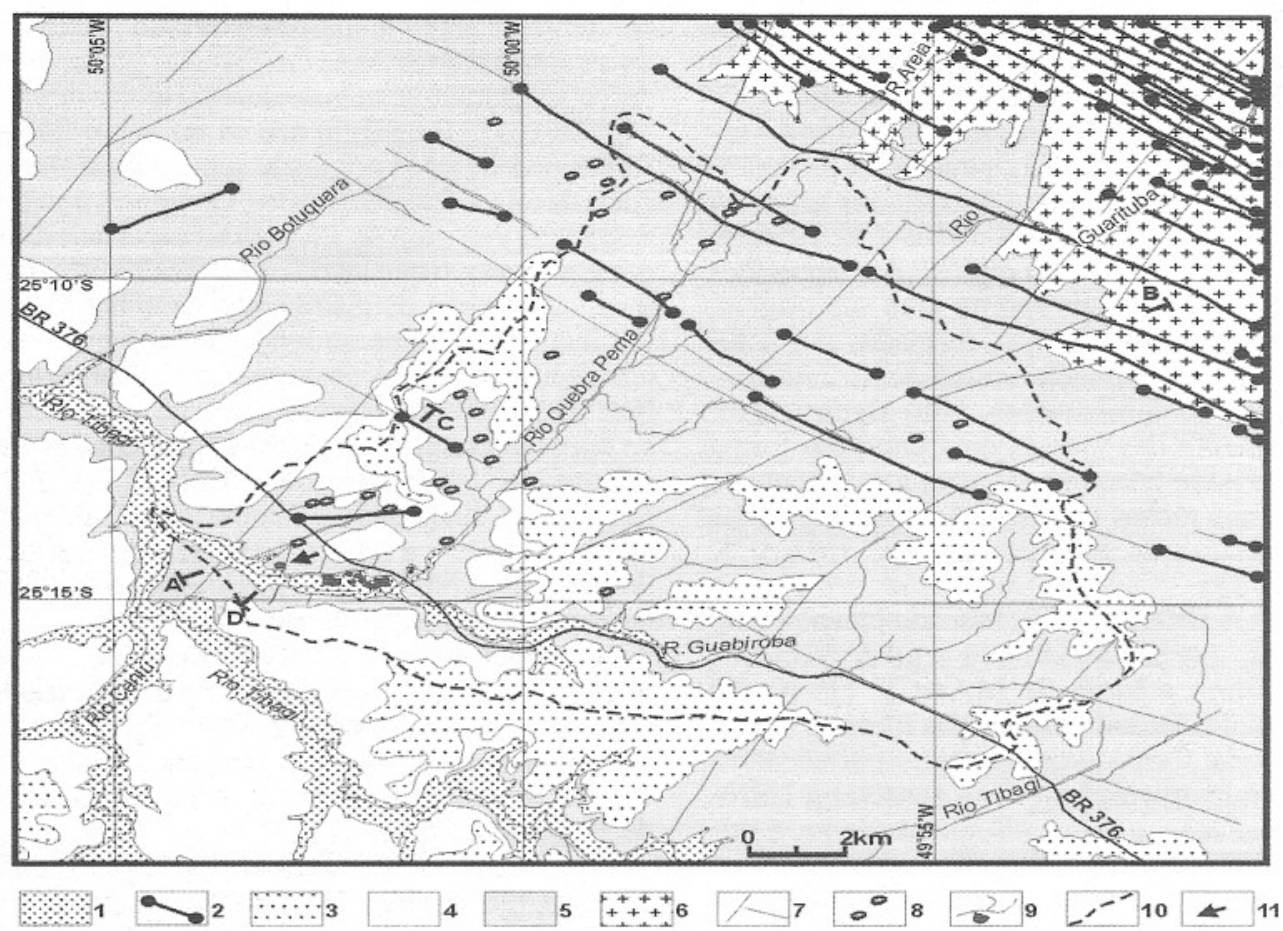

FIGURA 7 - Mapa geológico da região da bacia hidrográfica do Rio Guabiroba e Lagoa Dourada. 1: aluviões quaternários; 2: diques de diabásio; 3: Grupo Itararé; 4: Formação Ponta Grossa; 5: Formação Furnas; 6: embasamento; 7: principais estruturas (falhas e fraturas); 8: furnas; 9: rios e lagos; 10: limites da bacia hidrográfica do Rio Guabiroba; 11: Lagoa Dourada; A-B: posição da seção esquemática da Figura 5; C-D: posição da seção esquemática da Figura 8. Compilado de FUCK et al. 1965, TREIN et al. 1967, MAIA \& SOARES 1971, AGUIAR NETO 1977, SOARES 1989.

primeira vista parecem restos de crateras de extintos vulcões para depois acrescentar que se deve ao efeito do abatimento das camadas sedimentares do solo..." (TAUNAY 1948, apud SOARES 1989, p.3).

OLIVEIRA (1927) considerou as furnas como resultantes da dissolução mecânica devida à lavagem promovida pela água subterrânea em profundidade.

MAACK (1946) atribuiu os desabamentos verticais observados nas furnas e na Lagoa Dourada “... à existência de grutas subterrâneas, originadas pela decomposição dos calcáreos da série Açungui ou então pela remoção pelas águas subterrâneas de massas de caolim, respectivamente arcósio, na base do arenito Furnas..." (MAACK 1946 , p. 22). Afirmou também que "...o arenito das Furnas também é minado subterrâneamente, originando-se os buracos de desabamento (furnas) e poços em forma de dolinas, mediante desagregação por infiltração de água e sublavagem" (MAACK 1946, p. 254). A partir da constatação do mesmo nível d'água subterrânea nas furnas 1 , 2, 4 e Lagoa Dourada (Figura 8), admitiu uma “... ligação subterrânea com estas dolinas de desabamento..." (MAACK 1946, p. 254).

MAACK (1956), referindo-se às furnas 1 a 4 de Vila Velha, afirmou que "...As depressões

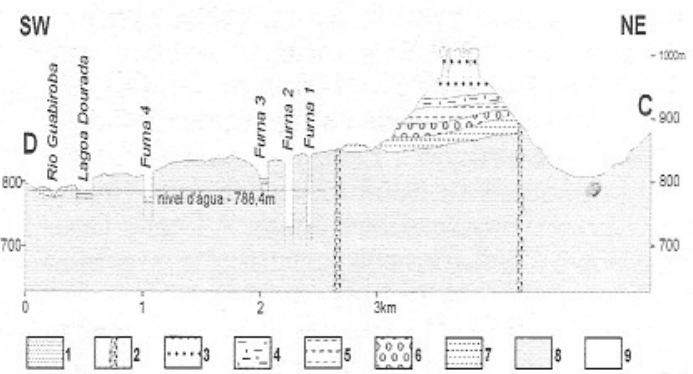

FIGURA 8 - Seção geológica èsquemática C-D (localização na Figura 7) através das furnas e da Lagoa Dourada. 1: sedimentos quaternários; 2 : diques de diabásio; 3: Arenito Vila Velha; 4: arenitos argilosos do Grupo Itararé; 5: argilito e folhelho do Grupo Itararé; 6: arenitos variegados do Grupo Itararé; 7: folhelhos da Formação Ponta Grossa; 8: Arenito Furnas; 9: lâmina d'água. Modificado de MAACK 1946.

doliniformes são originadas mediante desagregação por infiltração de água no arenito das Furnas, pela sublavagem devida à água subterrânea corrente e pelo consequente desmoronamento... Ainda não foi confirmado se este desabamento é causado por cavernas existentes no calcário da lapa da série Açunguí, o que é bem possível. Entretan- 
to, indubitavelmente existe uma ligação subterrânea de água corrente entre todas as furnas até a Lagôa Dourada, onde a água cristalina penetra por fendas e cavidades." (MAACK 1956, p. 154). Afirmou ainda que "... a água... penetra na profundidade, dissolvendo, assim, a ligação dos grãos ou cristais das rochas na lapa." (MAACK 1956, p. 154). Considerou também que "... As depressões afuniladas rasas são, de acôrdo com sua origem, formas legítimas de dolinas, formadas por soluções químicas e lixiviação consequente à infiltração seguida de desabamento... Em alguns casos, o desabamento das massas de arenito em forma de bancos pode relacionar-se com a existência de cavernas nas rochas calcárias na lapa, originadas pela correnteza da água de subsolo." (MAACK 1956, p. 155).

LE BRET (1974), baseado na coloração das águas, que seria devida a argilas coloidais, compartilhou a idéia de MAACK (1946) de intercomunicação subterrânea das furnas e da Lagoa Dourada. Considerou o Arenito Furnas praticamente impermeável e pouco sensível à corrosão e dissolução, e que, consequentemente, a origem dos desmoronamentos e formação dos abismos ou furnas deveria encontrar-se na formação de cavernas de dissolução em bolsões de calcário do substrato proterozóico abaixo do arenito. Destacou ainda que a furna 4 recebe os sedimentos transportados em um pequeno vale, encontrandose em processo de preenchimento, e que a Lagoa Dourada seria um antigo abismo, preenchido por sedimentos de procedência externa, provavelmente trazido pelos rios Guabiroba e Tibagi.

MAACK (1981) ponderou que "Ocorrências carstiformes no arenito das Furnas chamam a atenção especial... Trata-se de cavidades verticais denominadas FURNAS em forma de dolinas, com profundidades superiores a $100 \mathrm{~m}$ na fazenda Lagoa Dourada em Vila Velha e nos Campos Gerais em Joaquim Murtinho... Estes fenômenos interessantes originaram-se do desabamento em virtude de cavidades e erosão subterrâneas. A Lagoa Dourada também é uma formação carstiforme no arenito das Furnas." (MAACK 1981, p. 384).

SOARES (1989) descreveu pormenorizadamente as furnas em arenito dos Campos Gerais. Discutiu a impropriedade do termo "furna", apesar de consagrado na literatura e popularmente, considerando mais adequada a expressão "poço de desabamento". Organizou a hipótese genética que entende as furnas como consequiência de "... lenta dissolução, mas principalmente por erosão mecânica da água...”, processos que levam inicialmente à formação de abóbadas subterrâneas, que evoluem em direção à superfície controladas pelo cruzamento de fraturas e pela estratificação dos arenitos, até originar os desabamentos que formam as feições vistas superficialmente (SOARES 1989, p. 25).

SOARES \& REBELLO (1991), estudando a furna $\mathrm{n}^{\circ} 1$, ressaltaram que o corpo aquoso, no caso, não se enquadra na definição estrita de um lago, mas é uma exposição do lençol freático ao ambiente aéreo numa pequena área. Analisando a composição da água em diversas profundidades, constataram valores de dureza (teores de $\mathrm{Ca}$ e $\mathrm{Mg}$ ) baixos $(3,0 \mathrm{mg} / \mathrm{l})$, o que os fez supor que as furnas podem ter se originado sem qualquer influência de minerais carbonatados. Os valores de sílica dissolvida variaram de $1,5 \mathrm{mg} / \mathrm{l}$ na superfície a 4,9 $\mathrm{mg} / \mathrm{l}$ no fundo, o que levou os autores a afirmarem que "...O padrão de distribuição da sílica mostra um incremento rumo ao fundo. Pelas baixas porcentagens obtidas nas análises, torna-se difícil atribuir um processo de dissolução como sendo o único fator responsável pela formação do poço de desabamento." (SOARES \& REBELLO 1991, p. 5). Destacaram ainda que a comunicação subterrânea entre as furnas e a Lagoa Dourada existe através de pequenas fendas, e que o fluxo subterrâneo pode ter capacidade de dissolução e de transportar partículas nestes espaços. Relataram também que não foi possível coletar material de fundo, sugerindo que este é formado por blocos de rocha. Constataram uma variação da temperatura da água de $19,5^{\circ} \mathrm{C}$ na superfície para $9,5^{\circ} \mathrm{C}$ no fundo, cerca de 50 metros abaixo.

LORSCHEITTER \& TAKEDA (1995) apresentaram os resultados de estudo palinológico dos 5,68 metros inferiores de testemunho de sondagem que atingiu $12 \mathrm{~m}$ de profundidade. Concluíram pela existência de semi-aridez marcada por baixa concentração polínica no final do Pleistoceno (fase anterior a 11.000 anos AP), pela melhoria das condições climáticas, com elementos arbóreos mais freqüentes e diversificados no intervalo entre 11.000 e 8.000 anos AP, e melhoria ainda mais acentuada acima dos 8.000 anos AP, quando surge Araucaria no espectro polínico.

MORO (1998) estudou parâmetros físico-químicos e as comunidades de diatomáceas do mesmo testemunho de sondagem utilizado para o presente estudo sedimentológico da Lagoa Dourada. Concluiu que a lagoa foi sempre rasa, de água doce, com uma comunidade perifítica(que se fixa a um substrato) importante, abundante suprimento de oxigênio dissolvido e altas taxas de decomposição da matéria orgânica do sedimento. Determinou a existência de sete zonas distintas no testemunho, para as quais interpretou variações do paleonível d'água a partir do índice plâncton/ perifíton, e correlacionou-as a variações paleoclimáticas do intervalo estudado.

MORO (s.d.a) concluiu que "A Lagoa Dourada atravessou, nos últimos 12.000 anos, quatro fases hidrológicas sucessivas distintas: ao redor de 11.000 anos antes do presente (AP), um período relativamente árido se comparado ao regime climático atual; ao redor de 8.000 anos AP, uma acentuação da aridez com manutenção da lâmina d'água bastante escassa; a partir de 6.000 a 5.000 anos AP, vigência de condições climáticas mais amenas, com flutuações de menor escala. Num período mais recente, têm havido decréscimo do nível d'água e da produtividade da lagoa."

MORO (s.d.b) identificou nove diferen- 
tes comunidades de diatomáceas ao longo do testemunho da Lagoa Dourada, correlacionando-as com as fases hidrológicas e paleoclimáticas de seus trabalhos anteriores.

\subsection{Regime hidrológico da Lagoa Dourada}

A Lagoa Dourada pertence à bacia hidrográfica do Rio Guabiroba, ligando-se a ele através de um canal sinuoso com cerca de $220 \mathrm{~m}$ de extensão e praticamente nenhum desnível (Figura 3). O Rio Guabiroba, por sua vez, é um afluente do Rio Tibagi, o qual vai desaguar no Rio Paranapanema cerca de três centenas de quilômetros ao norte de Ponta Grossa.

Quando o Rio Guabiroba está em seu nível normal ou baixo, a Lagoa Dourada recebe a água de várias fontes (pelo menos cinco visíveis no terreno) em sua borda norte. Alguns autores admitem que estas fontes estejam associadas com a água subterrânea do complexo de furnas do Parque Estadual de Vila Velha, estas supostamente controladas por estruturas rúpteis de direção NNESSW a ENE-WSW (MAACK 1946 e 1956, LE BRET 1974, SOARES 1989). A água das fontes é cristalina, responsável pela limpidez das águas da lagoa, que a tornam um "aquário natural", onde se pode observar grande variedade de espécies de peixes que a procuram para desova.

As cheias dos rios Guabiroba e Tibagi ocorrem durante todo o ano, mas sobretudo nos meses de maio, junho, julho e outubro (Figura 4), quando, apesar da precipitação mensal acumulada ser menor do que nos meses de verão, as chuvas (do tipo frontal) são mais concentradas. Durante estas cheias, as águas do Rio Guabiroba refluem pelo canal de ligação com a Lagoa Dourada, inundando-a com águas turvas com grande quantidade de finos em suspensão. Nestas épocas, somente junto às fontes de águas subterrâneas pode-se observar alguma limpidez. O fluxo das águas subterrâneas, no entanto, não é suficiente para evitar que grande parte destes finos trazidos em suspensão decantem no interior da Lagoa Dourada.

Nos tempos mais recentes, com clima e regime hidrológicos próximos dos atuais, esta inundação periódica deve ser a principal responsável pelo assoreamento da Lagoa Dourada, suposta também uma feição de desabamento, semelhante às demais furnas, mas em avançado estado de assoreamento.

A proximidade do Rio Guabiroba, e a influência direta de suas cheias na lagoa, seriam os fatores determinantes do contraste entre as demais furnas, depressões com até 111 metros de profundidade com muito pouco ou nenhum sedimento, e a Lagoa Dourada, esta quase que totalmente assoreada.

$\mathrm{O}$ aporte de finos para dentro da Lagoa Dourada pelas cheias do Rio Guabiroba tem algumas conseqüências:

a) a lagoa não é um sistema fechado, mas faz parte da bacia hidrográfica do Rio Guabiroba:

b) os sedimentos que preenchem a Lagoa Dourada são provenientes da desintegração das rochas presentes em toda a bacia hidrográfica do Rio Guabiroba a montante da lagoa, e também das vertentes do entorno e das rochas atravessadas pelas águas subterrâneas que alimentam as fontes da borda norte da lagoa.

A atual profundidade da lâmina d'água da lagoa (0,4 a 5,4 metros) também reflete o aporte de sedimentos principalmente a partir do canal de conexão com o Rio Guabiroba. As profundidades menores encontram-se na porção sul e sudeste da lagoa, próximo ao canal de ligação, enquanto as profundidades maiores aparecem no terço norte a noroeste da lagoa.

Tal variação de profundidade párece estar refletindo a conjugação de dois fatores:

a) o aporte de sedimentos finos em suspensão a partir do Rio Guabiroba, através do canal de ligação com a lagoa; adentrando as águas calmas da lagoa, a tendência é de maior decantação nas proximidades do canal;

b) o contínuo fluxo de água subterrânea nas bordas norte e noroeste da lagoa (Figuras 3 e 9), contribuindo para a limpidez das águas nesses locais mesmo durante as cheias do Rio Guabiroba, dificultando a decantação dos finos em suspensão.

7.3 Alimentação pelas surgências de águas subterrâneas

Na borda norte da Lagoa Dourada observa-se a ocorrência de pelo menos cinco surgências de águas subterrâneas (Figura 3), que vertem água límpida em fluxo constante durante todo o ano. Essas surgências são as responsáveis pela transformação da lagoa num "aquário natural", sempre pleno de água, quase sempre límpidas (quando as enchentes não turvam a água subterrânea).

Dados de temperatura da água na Lagoa Dourada em várias estações apresentados por PRESTES (1991) e MORO (s.d.a) mostram valores entre $18,0 \mathrm{e} 21,6^{\circ} \mathrm{C}$, altos em relação à temperatura do ar, sugerindo que as águas subterrâneas que alimentam a lagoa são relativamente quentes.

Muitas espécies de peixes (curimbatás, tubaranas, traíras, lambaris, carás e outros, já estudados por MORAES, 1995) aparecem ali em grande quantidade, e conferem ao local os atributos de uma atração turística e científica procurada por gente de várias procedências. Algumas das espécies de peixes tão comuns na lagoa são raras nos rios da região, pois exigem águas mais quentes que as que existem no Segundo Planalto Paranaense.

Entretanto, aparentemente a temperatura relativamente elevada da água subterrânea que alimenta a lagoa, principalmente nos meses de inverno, a mansidão e a limpidez das águas fazem da Lagoa Dourada um local ideal para a reprodução 


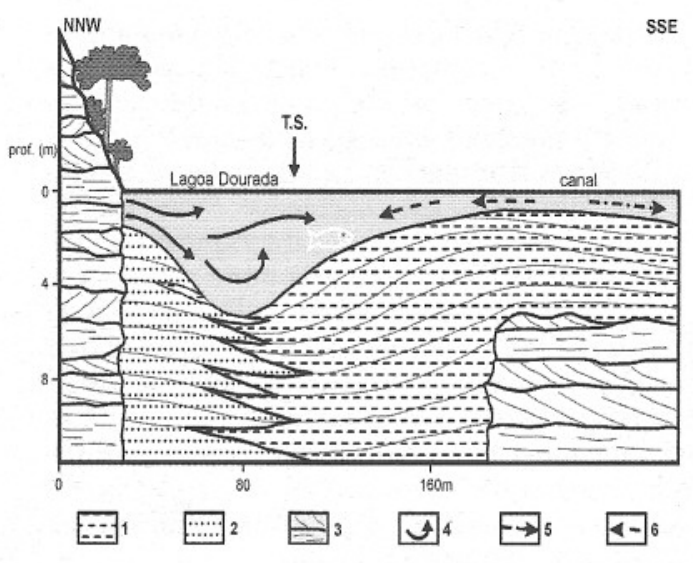

FIGURA 9 - Seção geológica hipotética através da Lagoa Dourada. 1: sedimentos silto-argilosos; 2: sedimentos arenosos; 3: Formação Furnas; 4: fluxo das fontes subterrâneas; 5: fluxo normal da água; 6: refluxo durante as cheias do rio Guabiroba; T.S.: posição do testemunho de sondagem.

dos peixes, inclusive daqueles (como o curimbatá) que exigem águas com temperaturas relativamente mais elevadas, e por isso são raros nos rios da região.

A alimentação pelas águas subterrâneas também influencia o $\mathrm{pH}$ das águas da Lagoa Dourada. Medidas do $\mathrm{pH}$ das águas de superfície realizadas por PRESTES (1991) e por MORO (1998) apresentaram valores variando de 8,1 (no canal de ligação com o Rio Guabiroba) a 6,5 (no terço norte da lagoa, próximo às surgências de águas subterrâneas). SOARES \& REBELLO (1991) mostraram variação das águas na furna $\mathrm{n}^{\circ} 1$ do Parque Estadual de Vila Velha, desde 6,06 na superfície até 5,74 (20 $\mathrm{m}$ de profundidade) e 5,90 (30 $\mathrm{m}$ de profundidade). Estas duas situações indicam que as águas subterrâneas são ligeiramente mais ácidas que as águas superficiais, na Lagoa Dourada e na furna $n^{\circ} 1$.

A surgência das águas subterrâneas também influencia a geometria e constituição do pacote sedimentar que preenche a Lagoa Dourada (Figura 9). A profundidade da lâmina d'água é maior na porção norte, onde o fluxo constante da água subterrânea mantém as águas límpidas mesmo durante as cheias, dificultando a decantação dos finos em suspensão. Por outro lado, observase que predomina material arenoso na superfície de fundo junto à borda norte, enquanto no restante da lagoa predomina material fino.

\section{ANÁLISE DOS SEDIMENTOS DA LAGOA DOURADA}

No estudo do testemunho de sondagem da Lagoa Dourada (MELO 1999, MELO et al. s.d.a e s.d.b, Figura 10), procurou-se caracterizar os sedimentos, suas variações significativas em composição, textura e estrutura, e as possíveis relações com processos deposicionais e deformacionais, regime hidrológico da lagoa e bacia hidrográfica e variações paleoambientais. São sintetizados a seguir os principais resultados desses estudos.

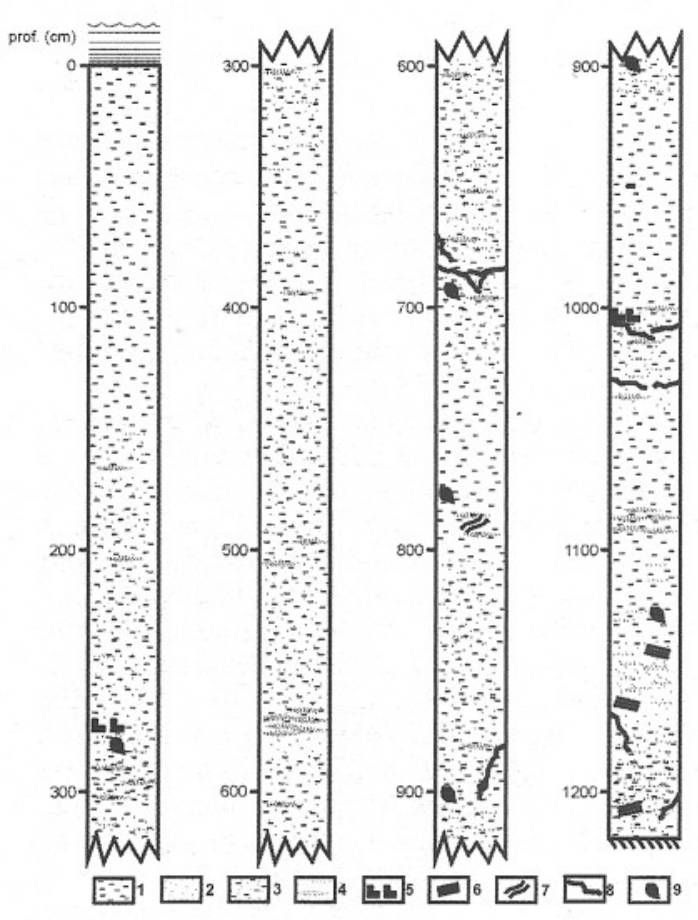

FIGURA 10 - Testemunho de sondagem dos sedimentos da Lagoa Dourada. 1: argila; 2: areia muito fina; 3 : argila com pouca areia muito fina; 4: lâminas milimétricas e lentes centimétricas de areia muito fina; 5: gipso; 6: inclinação da laminação; 7 : deformação da laminação; 8: rupturas; 9: restos vegetais.

\section{1 Áreas-fontes}

Considerando-se que a Lagoa Dourada recebe águas de inundação do Rio Guabiroba, as unidades geológicas presentes na área-fonte de seus sedimentos são aquelas que ocorrem na bacia hidrográfica deste rio, a montante da lagoa (Figura 7). Estas unidades geológicas são o Arenito Furnas (arenitos claros, arcoseanos a caulínicos), a Formação Ponta Grossa (folhelhos e arenitos finos) e rochas da base do Grupo Itararé (arenitos vermelhos a claros, lentes conglomeráticas, diamictitos, ritmitos, argilitos e folhelhos).

Pode-se considerar ainda a existência de uma variação lateral significativa na proveniência e constituição dos sedimentos, observada em superfície nos trabalhos de campo, mas não investigada em subsuperfície. Esta variação lateral dá conta de:

a) presença de lobos essencialmente arenosos, derivaḑos principalmente da desagregação do Arenito Furnas; tais lobos, com uma extensão superficial visível de apenas alguns metros, 
ocorrem junto às surgências de águas subterrâneas límpidas, na borda norte da Lagoa Dourada (Figura 3);

b) presença de leitos predominantemente finos (argila e pouco silte e areia muito fina) no restante da lagoa; são sedimentos trazidos principalmente em suspensão durante as cheias do Rio Guabiroba, quando as águas barrentas invadem a lagoa e ali permanecem decantando vários dias; mesmo no canal de conexão entre a Lagoa Dourada e o Rio Guabiroba o material observado superficialmente é argiloso, indicando que os processos trativos são pouco significativos no assoreamento da lagoa.

Observa-se também (Figura 3) alguns bancos de assoreamento recentes formados por material argiloso vermelho-amarelado proveniente de solos de sedimentos aluviais na borda sul da lagoa. Tais bancos são decorrentes de processos erosivos marginais (erosão laminar, sulcos de erosão) em decorrência das trilhas e áreas de pisoteio em consequiência da intensa visitação turística concentrada naquele local.

Vários fatores sugerem que o aporte sedimentar proveniente diretamente da bacia de captação exclusiva da Lagoa Dourada seja insignificante. São eles:

a) a presença ainda hoje de rupturas de declive associadas a paredões rochosos verticais na borda norte da lagoa, e a forma aproximadamente circular desta, revelando tratar-se de uma estrutura semelhante às demais furnas do Parque Estadual de Vila Velha, das quais se diferencia por encontrar-se assoreada;

b) o fato de as outras furnas, livres da invasão de águas de transbordamento de rios, não apresentarem sedimentação significativa;

c) a presença de mata ciliar natural evoluída nas bordas da lagoa, apresentando inclusive Araucaria, palmeiras e taquaras; esta mata protege o solo de processos erosivos, restringindo o aporte de sedimentos das encostas marginais diretamente para a lagoa.

\subsection{Mineralogia dos grãos}

Nas análises mineralógicas de grãos de minerais pesados nos sedimentos da surgência de água subterrânea na Lagoa Dourada, a ocorrência de silimanita e coríndon aponta para uma derivação a partir da Formação Furnas. Epídoto e anatásio, ambos com presença acentuada nos sedimentos da surgência, podem ter sido fornecidos preferencialmente devido a seu caráter de preenchimento, diagenético ou hidrotermal, dos interstícios atravessados pelo fluxo subterrâneo (MELO et al. s.d.a).

Uma outra possibilidade é que a associação epídoto-coríndon observada nos sedimentos da surgência de água subterrânea esteja refletindo contribuição de rochas metamórficas de baixo grau ricas em alumínio, representadas na região por metassedimentos do Supergrupo Açungui, situados no embasamento das unidades da Bacia do Paraná. Neste caso seria necessário admitir que parte da água subterrânea que ressurge na Lagoa Dourada pudesse provir de grandes profundidades (mais de 300 metros, espessura da Formação Furnas na área), transportando grãos dos metassedimentos subjacentes. Outros argumentos favoráveis a esta hipótese são:

a) a localização das furnas (entre elas a Lagoa Dourada) preferencialmente sobre a continuidade, para sob as rochas sedimentares da $\mathrm{Ba}$ cia do Paraná, dos metassedimentos da Faixa Itaiacoca (Figura 6);

b) as temperaturas das águas das surgências na Lagoa Dourada (PRESTES 1991 e MORO 1998) são superiores às temperaturas observadas no fundo das águas da furna ${ }^{\circ} 1$ do Parque Estadual de Vila Velha (SOARES \& REBELLO 1991).

\subsection{Argilominerais}

Visto que as rochas presentes nas áreasfontes da Lagoa Dourada são portadoras de clorita, ilita e interestratificados ilita - montmorilonita (RAMOS \& FORMOSO 1975), e que estes argilominerais tendem a transformar-se em caulinita e gibbsita nos horizontes superficiais dos solos tropicais com chuvas bem distribuídas, podese afirmar que a presença de clorita e interestratificados detríticos nos sedimentos da Lagoa Dourada poderiam significar:

a) fases de bio-resistasia, desencadeadas por mudanças climáticas, com erosão acentuada e exposição de horizontes inferiores do solo;

b) fases de climas mais secos, com chuvas mais escassas e concentradas.

Entretanto, nos sedimentos da Lagoa Dourada só foram encontrados caulinita e ilita entre os argilominerais (MELO et al. s.d.a). Se fases paleoclimáticas mais secas existiram durante a sedimentação na lagoa, o que é sugerido poŕ outros indícios, ou elas não propiciaram a erosão e deposição dos argilominerais mais instáveis sem alteração, ou as análises realizadas não foram suficientes para detectá-los.

\subsection{Minerais autígenos}

Os minerais autígenos mais significativos detectados nas análises realizadas nos sedimentos da Lagoa Dourada foram o gipso a pirita (MELO et al. s.d.a e s.d.b). Aparecem em muito pouca quantidade, em cristais microscópicos. O gipso é um dos primeiros evaporitos a se formar a partir de salmouras, quando a salinidade aumenta por efeito da evaporação. A presença de gipso pode, assim, estar marcando eventos de aumento da evaporação, talvez em consequiência de fases climáticas mais secas. A ocorrência de pirita associada ao gipso pode refletir a ausência de oxigênio dissolvido na água, em razão de altas taxas de salinidade. A associação de pirita e gipso conver- 
ge para a interpretação de fases de aumento da salinidade das águas da lagoa.

\subsection{Isótopos de carbono}

No geral, a porcentagem de carbono total nos sedimentos da Lagoa Dourada é relativamente baixa $(0,11$ a $0,83 \%)$, corroborando resultados do conteúdo de matéria orgânica obtidos por MORO (1998), que os interpretou como sugestivos de sedimentação sempre sob lâmina d'água rasa, com abundante suprimento de oxigênio dissolvido, e conseqüente decomposição da matéria orgânica depositada.

Os valores de $\delta^{13} \mathrm{C}\left({ }^{13} \mathrm{C} /{ }^{12} \mathrm{C}\right)$ dos sedimentos da Lagoa Dourada não mostram tendências de variações nítidas, que possam ser interpretadas como resultantes de importantes mudanças na cobertura vegetal, e consequentemente no clima. Os valores indicam predominância de plantas arbóreas e gramíneas de clima mais úmido, com presença subordinada de gramíneas típicas de climas mais secos.

Estes dados são sugestivos de que o aporte de matéria orgânica pelo menos nos últimos 11.110 anos na Lagoa Dourada tenha se dado a partir de uma cobertura vegetal muito próxima da atual, com matas ciliares e capões esparsos em campos limpos do tipo savana gramíneo-lenhosa, compondo cobertura vegetal do tipo Floresta Ombrófila Mista (VELOSO \& GÓES FILHO 1982).

\subsection{Granulometria}

As observações do testemunho de sondagem (Figura 10) e dos sedimentos da superfície de fundo da Lagoa Dourada mostram que o material é predominantemente silto-argiloso nos dois terços de sul e sudeste, passando a arenoso no terço norte e noroeste (Figura 9).

Poucas são as intercalações de lâminas milimétricas e/ou lentes centimétricas de areia fina nos sedimentos predominantemente silto-argilosos do testemunho da Lagoa Dourada. Estas intercalações arenosas devem provir de duas fontes:

a) a principal, o material arenoso proveniente dos condutos (fraturas) que permitem a surgência da água subterrânea no interior da lagoa;

b) material arenoso transportado durante as enchentes do Rio Guabiroba, que provocam o refluxo da água, que retorna ao interior da lagoa.

Já o material fino silto-argiloso que constitui o principal preenchimento da Lagoa Dourada provém principalmente das águas turvas das enchentes do Rio Guabiroba.

\subsection{Espessura}

A espessura total dos sedimentos da La- goa Dourada não é conhecida. Durante a obtenção do testemunho de sondagem analisado por LORSCHEITTER \& TAKEDA (1995), MORO (1998) e MELO (1999), a espessura amostrada (12,2 metros) foi determinada pela operacionalidade do equipamento utilizado.

Levando-se em conta a profundidade das furnas n ${ }^{\circ} 1,2$ e 4 do Parque Estadual de Vila Velha (Figura 8), não se pode descartar a hipótese de que a Lagoa Dourada apresente espessura de sedimentos até da ordem de meia centena de metros. Estudos futuros de geofísica de alta resolução e mesmo nova testemunhagem deverão revelar a espessura total dos sedimentos da Lagoa Dourada.

\subsection{Datações ${ }^{14} \mathrm{C}$ e taxas de sedimentação}

São reportadas duas datações radiométricas em material proveniente dos sedimentos da Lagoa Dourada (LORSCHEITTER \& TAKEDA 1995, MORO 1998), conforme segue: $8.720 \pm 150$ anos AP na profundidade 10,6 metros e $11.170 \pm 110$ anos AP na profundidade 11,9 metros. Baseando-se somente nessas duas datações, obtém-se as seguintes taxas de sedimentação para a Lagoa Dourada:

\begin{tabular}{|l|c|}
\hline intervalo $(\mathrm{m})$ & $\begin{array}{c}\text { taxa de sedimentação } \\
(\mathrm{mm} / \text { ano })\end{array}$ \\
$10,6-0$ & 1,22 \\
$11,9-10,6$ & 0,53 \\
\hline
\end{tabular}

Ainda que os valores obtidos sejam muito aproximados, tendo em vista o pequeno número de datações, pode-se fazer alguns comentários. A diferença entre tais taxas de sedimentação deve em grande parte ser atribuída à compactação dos sedimentos inferiores mais antigos, visto que no testemunho não são observadas descontinuidades sugestivas de hiatos erosivos ou fenômenos de deformação. As taxas de sedimentação relativamente altas na Lagoa Dourada, mesmo para os sedimentos inferiores já mais compactados, são sugestivas de que a invasão pelas águas turvas do Rio Guabiroba durante as inundações tem se constituído num processo determinante no assoreamento da lagoa no intervalo testemunhado. Tal suposição é reforçada pela comparação das taxas de sedimentação da Lagoa Dourada com aquelas da Lagoa do Infernão (LOBO 1997), justamente um caso de lagoa holocênica (3.500 anos) em planície de inundação (Rio Moji-Guaçu em São Paulo).

\section{CONCLUSÕES}

A Lagoa Dourada é uma das furnas do Parque Estadual de Vila Velha, alinhadas sobre estrutura rúptil de direção NNE-SSW. As furnas são feições de desabamento no teto de erosões 
subterrâneas promovidas nos arenitos da Formação Furnas, preferencialmente ao longo de estruturas rúpteis (falhas, fraturas) geradas e reativadas no Mesozóico, durante o paroxismo do Arco de Ponta Grossa. A Lagoa Dourada não é um sistema fechado, visto que recebe águas turvas das inundações do Rio Guabiroba. Os sedimentos que a preenchem são provenientes das rochas presentes no seu entorno imediato, das rochas no percurso das águas subterrâneas que alimentam as fontes de sua borda norte, e das rochas em toda a bacia hidrográfica do Rio Guabiroba a montante da lagoa.

As unidades geológicas na bacia hidrográfica do Rio Guabiroba são o Arenito Furnas (arenitos claros, arcoseanos a caulínicos), a Formação Ponta Grossa (folhelhos e arenitos finos) e rochas do Grupo Itararé (arenitos vermelhos a claros, lentes conglomeráticas, diamictitos, ritmitos, argilitos e folhelhos).

$\mathrm{O}$ sedimento que preenche a Lagoa Dourada é predominantemente silto-argiloso nos dois terços de sul e sudeste, passando a arenoso no terço norte e noroeste. O material fino siltoargiloso provém principalmente das águas turvas das enchentes do Rio Guabiroba, o material arenoso provém dos condutos (fraturas) que permitem a surgência da água subterrânea no interior da lagoa.

As taxas de sedimentação relativamente altas na Lagoa Dourada, comparáveis às de outras lagoas em planícies de inundação, reforçam a suposição de que a invasão pelas águas turvas do Rio Guabiroba durante as inundações tem se constituído num processo determinante no assoreamento da lagoa em todo o intervalo testemunhado.

Nos sedimentos arenosos das surgências de água subterrânea, a ocorrência acentuada de epídoto e anatásio entre os minerais pesados pode ter duas explicações:

a) podem ser minerais de preenchimento, diagenético ou hidrotermal, dos interstícios do Arenito Furnas profundo, atravessado pelo fluxo subterrâneo;

b) derivação a partir de rochas metamórficas de baixo grau ricas em alumínio, representadas na região por metassedimentos do Supergrupo Açungui, situados no embasamento das unidades da Bacia do Paraná.

Nesta segunda hipótese, seria necessário admitir que parte da água subterrânea que ressurge na Lagoa Dourada pudesse provir de grandes profundidades (mais de 300 metros, espessura da Formação Furnas na área), transportando grãos dos metassedimentos subjacentes. Isto conduziria à antiga hipótese de que a origem das furnas possa estar relacionada com fenômenos de erosão subterrânea profundos, incluindo dissolução (MAACK 1946 e 1956).

A ocorrência de gipso, às vezes associado a pirita, ambos como minerais autígenos nos sedimentos da lagoa, sugere fases de aumento da salinidade das águas durante a sedimentação, relacionadas a maior evaporação em climas mais secos.

É possível distinguir três "ciclos" de aumento das taxas de carbono total nos sedimentos da lagoa, que aparentemente coincidem com o aumento das relações isotópicas ${ }^{13} \mathrm{C} /{ }^{12} \mathrm{C}\left(\delta^{13} \mathrm{C}\right)$. Diversas hipóteses podem explicar a existência de tais "ciclos": sucessão de condições de maior ou menor decomposição da matéria orgânica dos sedimentos; variaçõ̂es na cobertura vegetal, com maior participação de plantas tipo $\mathrm{C}$ e conseqüente incremento em $\delta^{13} \mathrm{C}$, sugerindo têndências para fases climáticas mais secas; variações na salinidade da água da lagoa.

Não se pode afirmar, com base nos estudos realizados, a idade da Lagoa Dourada. Ela certamente é mais antiga que 11.170 anos, datação dos restos vegetais da base do testemunho de sondagem coletado, o qual não atingiu o embasamento dos sedimentos. Por outro lado, algumas das furnas não devem ser feições antigas, como sugere a furna $n^{\circ} 4$ do Parque Estadual de Vila Velha, a qual situa-se no leito do Córrego da Roça, seco a jusante da furna. Pode-se especular que a erosão subterrânea que origina as furnas tenha maior eficiência durante fases de pronunciado rebaixamento do lençol freático, o que acontece durante as fases de clima mais seco associadas aos períodos glaciais do Pleistoceno.

A região dos Campos Gerais apresenta várias depressões do tipo das furnas (Lagoa Tarumã, Lagoa do Coração, furnas de Vila Velha, Lagoa Bonita e outras), algumas fechadas, que contêm um preenchimento sedimentar que pode constituir-se num rico registro de variações paleoambientais quaternárias no Sul do Brasil, e que deve ser investigado com o devido detalhamento.

\section{AGRADECIMENTOS}

Ao Conselho Nacional de Desenvolvimento Científico e Tecnológico- CNPq (Processo 300272/ 97-9). A Max Brandt Neto e Luiz Alberto Fernandes, pela obtençao e interpretação de imagens dos sedimentos por microscopia eletrônica de varredura.

\section{REFERÊNCIAS BIBLIOGRÁFICAS}

AB'SÁBER, A.N. 1977. Topografias ruineformes no Brasil. São Paulo: Instituto de Geografia USP,14p. (Geomorfologia, 50).

AGUIAR NETO, A. 1977. Folha Ponta Grossa (SG-22-X-C-II-2), escala 1:50.000. Comissão da Carta Geológica do Paraná - Projeto Leste do Paraná, Convênio CPRM DNPM - BADEP - UFPR.

FAMEPAR - Instituto de Assistência aos Municípios do Estado do Paraná. 1995. Levanta- 
mento aerofotogramétrico do espaço urbano de Ponta Grossa em escala 1:8.000. Curitiba, Engefoto.

FAMEPAR - PMPG - Instituto de Assistência aos Municípios do Estado do Paraná e Prefeitura Municipal de Ponta Grossa. Plantas planialtimétricas do espaço urbano de Ponta Grossa em escala 1:2.000. Curitiba, Engefoto.

FUCK, R.A.; TREIN, E.; LOPES, J.A. 1965. FOlha geológica de Quero-Quero escala 1:50.000. Curitiba, Comissão da Carta Geológica do Paraná.

ITC - PR - Instituto de Terras e Colonização do Estado do Paraná. 1980. Levantamento aerofotogramétrico do Estado do Paraná em escala 1:25.000. Curitiba, Aerosul.

LE BRET, M. 1974. As furnas de Vila Velha Paraná: um caso de desmoronamento kárstico no arenito. São Paulo, Sociedade Brasileira de Espeleologia, 6p. (texto mimeografado inédito) (tradução Guy C. Collet).

LOBO, I. 1997. Uso de traçadores químicos e isotópicos no estudo paleoambiental da Lagoa do Infernão: uma lagoa marginal do Rio Moji-Guaçu, estação ecológica de Jataí, Luiz Antonio, SP. Departamento de Química, Universidade Federal de São Carlos, Tese de Doutoramento, 114p.

LORSCHEITTER, M.L.; TAKEDA, I.J.M. 1995. Reconstituição paleoambiental da região dos Campos Gerais, Paraná, através da palinologia de sedimentos da Lagoa Dourada. In: ABEQUA, CONGRESSO DA ASSOCIAÇÃO BRASILEIRA DE ESTUDOS DO QUATERNÁRIO, 5, Niterói, Anais..., p.18-21.

MAACK, R. 1946. Geologia e geografia da região de Vila Velha e consideraçđes sobre a glaciação carbonífera do Brasil. Curitiba, Arquivos do Museu Paranaense,v.5, 305p.

— 1948. Notas preliminares sobre clima, solos e vegetação do Estado do Paraná. Curitiba, Arquivos de Biologia e Tecnologia, 2:102200.

— 1956. Fenômenos carstiformes de natureza climática e estrutural de arenitos do Estado do Paraná. Curitiba, Arquivos de Biologia e Tecnologia, 11: 151-162.

— 1981. Geografia física do Estado do Paraná. Rio de Janeiro, Livraria José Olympio Ed., 442p.

MAIA, S.; SOARES, P.C. 1971. Folha SG - 22 - J - II, escala 1:100.000. Mapa Geológico de Semi-detalhe do Centro Leste do Paraná. PETROBRÁS - DESUL. Relatório DESUL n.400.

MELO, M.S. 1999. Análise sedimentológica dos depósitos da Lagoa Dourada, Vila Velha, Ponta Grossa, PR. Ponta Grossa, UEPG, Relatório Final de Pesquisa, 74p. (inédito).
2000. Lagoa Dourada, furna assoreada do Parque Estadual de Vila Velha, Ponta Grossa, PR. In: C. SCHOBBENHAUS (Ed.), Sítios geológicos e paleontológicos do Brasil. Brasília, Universidade de Brasília. Disponível em 16/12/00 na World Wide Web http://www.unb.br/ig/sigep/

—; COIMBRA, A.M. 1996 Ruiniform relief in sandstones: the example of Vila Velha, Carboniferous of the Paraná Basin, Southern Brazil. Acta Geológica Hispanica, 31(4): 25-40 (publicado em 1999).

; GIANNINI, P.C.F.; PESSENDA, L.C.R.; BRANDT NETO, M. s.d.a. Preenchimento sedimentar da Lagoa Dourada, Ponta Grossa, PR. Curitiba, Boletim Paranaense de Geociências (no prelo).

— $;-;-;-$ s.d.b. Holocene paleoclimatic evidence in the Lagoa Dourada deposits, Paraná State, South of Brazil. (inédito)

MINEROPAR - Minerais do Paraná do Paraná S/ A. 1989. Mapa Geológico do Estado do Paraná: escala 1:650.000. MINEROPAR, Curitiba.

MORAES, M.F.P.G. 1995. Estudo do tubo digestivo e do hábito alimentar de Hoplias malabaricus, Geophagus brasiliensis e Prochilodus lineatus (Osteichthytes, Teleostei) da lagoa Dourada, Ponta Grossa, Paraná. Setor de Ciências Biológicas, Curso de Pós-Graduação em Ciências Biológicas - Zoologia, UFPR, Curitiba, Dissertação de Mestrado, 116p.

MORO, R.S. 1998. Interpretações paleocológicas do Quaternário através da análise de diatomáceas (Bacillariophyta) nos sedimentos da Lagoa Dourada, Ponta Grossa, PR. Instituto de Biociências, Universidade Estadual Paulista, Rio Claro, Tese de Doutorado, 141p.

— s.d.a. Evolução trófica em um testemunho abrangendo o fim do Pleistoceno e Holoceno da Lagoa Dourada, Ponta Grossa, PR. (inédito).

s.d.b. Inferências paleolimnológicas do Pleistoceno tardio e Holoceno na Lagoa Dourada, Ponta Grossa, PR, através da análise de comunidades de diatomáceas (Bacillariophyta). (inédito).

OLIVEIRA, E.P. 1927. Geologia e recursos minerais do Estado do Paraná. Rio de Janeiro, Ministério da Agricultura, Indústria e Comércio, Serviço Geológico e Mineralógico do Brasil, 172p. (Monografia VI).

PRESTES, P.V. 1991. Condições físico-químicas das águas de Furna 1 e Lagoa Dourada, Parque Estadual de Vila Velha, Ponta Grossa, PR. Curitiba, PUC/ESAM, Monografia de Especialização, 84p.

RADAMBRASIL - Projeto Radambrasil. 1976. 
Mosaico semicontrolado de radar - Folha SG.22-X-C, escala 1:250.000. Departamento Nacional da Produção Mineral.

RAMOS, A.N.; FORMOSO, M.L.L. 1975. Argilominerais das rochas sedimentares da Bacia do Paraná. Rio de Janeiro, Ciência Técnica - Petróleo, Seção Exploração de Petróleo, (9): 72 e anexos.

SOARES, O. 1989. Furnas dos Campos Gerais, Paraná. Curitiba, Editora da UFPR, Scientia et Labor, 82p. (Série Didática).

SOARES, C.R.; REBELLO, J. 1991. Nota sobre a origem geomorfológica e os parâmetros físico-químicos e biológicos da coluna d'água da furna $\mathrm{n}^{\circ} 1$ - Parque Estadual de Vila Velha (Estado do Paraná). In: CONGRESSO BRASILEIRO DE ESPELEOLOGIA, 21, Curitiba, (separa- ta, 15p.).

TREIN, E.; MARINI, O.J.; FUCK, R.A. 1967. Folha geológica de Itaiacoca escala 1:50.000. Curitiba, Comissão da Carta Geológica do Paraná.

VELOSO, H.P.; GÓES FILHO, L. 1982. Fitogeografia brasileira - classificação fisionômica-ecológica da vegetação neotropical. Salvador: Projeto RADAMBRASIL, p.1-80 (Boletim Técnico, Série Vegetação, 1).

ZALÁN, P.V.; WOLFF, S.; CONCEIÇÃO, J.C.J.; MARQUES, A.; ASTOLFI, M.A.M.; VIEIRA, I.S.; APPI, V.T.; ZANOTTO, O.A. 1991. Bacia do Paraná. In: G.P.R. GABAGLIA \& E.J. MILANI (Coords.) Origem e evolução de bacias sedimentares. Rio de Janeiro, PETROBRÁS, p.135-168.

Endereço do autor:

Mário Sérgio de Melo -Universidade Estadual de Ponta Grossa, Departamento de Geociências, Av. Carlos Cavalcanti 4748, CEP 84030-000, Ponta Grossa, PR, Brasil. E-mail: msmelo@uepg.br. 